\title{
ACADEMIC CONFERENCE "IS THIS THE END OF THE THEORY OF LAW?" SEPTEMBER 21-24, 2011
}

\author{
KATARZYNA SCHMIDT ${ }^{*}$
}

On September 21-24, 2011, the Chair of Theory and Philosophy of Law in the Faculty of Law, Administration and Economy of the University of Wroclaw held an academic conference in the town of Karpacz entitled "Is this the end of the theory of law?". The main goal in selecting such a subject for the conference was to initiate a discussion focused on the analysis of the condition of the legal theory research programme. The question about the end of theory also hinted at the necessity of examining the state of Polish legal theory scholarship. The reason for selecting such a title for the conference was to raise doubts about the condition of the Polish theory of law, as well as to induce the conference participants to polemicize with one another on this controversial problem. The second area of interest was the issue of the status, tasks and profile of the Polish theory of law viewed as a research discipline. The crisis of the research programme, which was dominant not so long ago, gave rise to questions about the future nature of jurisprudence. The problem outlined above was the point of departure for discussions covering a number of topics. The meeting was dominated by the question in the title.

The majority of papers presented during the academic session were published before the conference in a work entitled "Czy koniec teorii prawa?" [Is this the end of the theory of law?]. For the eleventh time, an academic session was preceded by the publication of a study within the series entitled "Z zagadnień teorii i filozofii prawa" [Issues of the theory and philosophy of $l a w]$. The publication of the conference papers made them available to a great number of addressees.

The conference was opened by Professor W. Gromski, the Dean of the Faculty of Law, Administration and Economy and Professor A. Bator, the Head of the Chair of Theory and Philosophy of Law in the Faculty of Law, Administration and Economy of the University of Wroclaw. The conference, encompassing 16 lectures, was divided into four parts. Each thematic part closed with a discussion concerning the problems addressed by the participants. During the sessions, the question of the future of the theory of

DOI: $10.2478 /$ wrlae-2013-0033

* PhD candidate; LLM; Chair of Theory and Philosophy of Law, University of Wroclaw; k.schmidt@prawo.uni.wroc.pl 
law was a recurring theme. In addition, the issue of the relation between the theory of law and legal dogma was a dominant topic. A thesis concerning changes in the balance between the theory and the philosophy of law was also considered. Undoubtedly, the basic facts which the participants learned from the texts printed before the conference increased the quality of the discussion as they allowed the polemics to take a multidimensional aspect, and the discussants were able to refer to parts of the texts related to the topic under discussion.

In summary, it was noticeable that the theme chosen by the organisers for the conference served to provoke a discussion about the condition and the future of the theory of law. The meeting's participants presented various diagnoses and ways out of the crisis. The diversity of lecture topics made it an occasion for considering each problem from many points of view. Therefore, it can be declared that the question in the title presented a sort of intellectual provocation, leading to a discussion which has continued beyond the last day of the conference. 